JDHT Journal of Dental Hygiene and Therapy

Volume 1, Nomor 1 Tahun 2020

eISSN : xxxx-xxxx, DOI: xx.xxxxx/jdht.vxix.xx

\title{
PENATALAKSANAAN APD PADA PETUGAS KESEHATAN GIGI DI PUSKESMAS KECAMATAN KEPULAUAN SERIBU UTARA
}

\author{
Virginia Rizkaevita ${ }^{1}$, Widi Nurwanti ${ }^{1}$
}

${ }^{1}$ Akademi Kesehatan Gigi Pusat Kesehatan Angkatan Darat, Indonesia

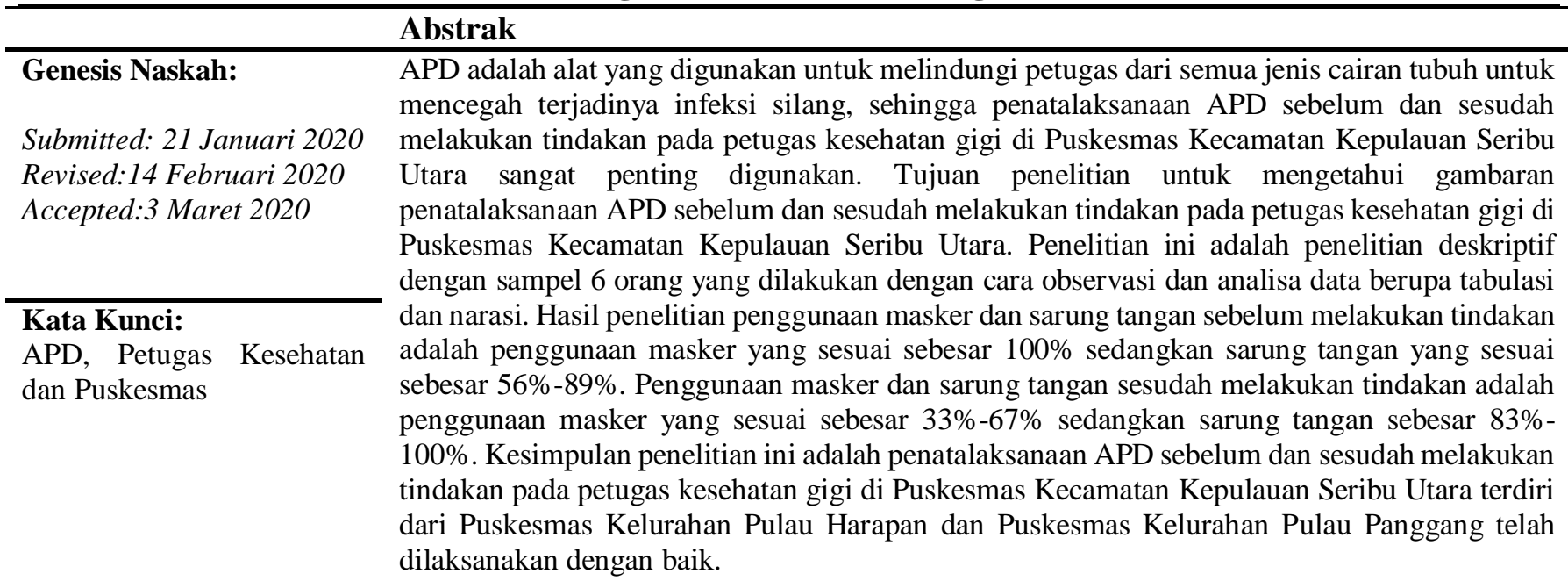

\section{OVERVIEW OF PPE MANAGEMENT OF THE DENTAL HEALTH WORKER IN DISTRICT OF NORTH KEPULAUAN SERIBU PUBLIC HEALTH CENTER}

\begin{tabular}{ll}
\hline Keywords: & Abstract \\
PPE, Health Officers and and Health Centers. & PPE (Personal Protective Equipment) is a tool used to protect staff from all types of fluids for \\
the prevention of cross infection, so that the management of PPE before and after taking action \\
on dental health workers in the Public Health Center of North Kepulauan Seribu is very \\
important to use. The purpose of this study is to determine the description of PPE management \\
before and after taking action on dental health workers in the Public Health Center of North \\
Kepuluan Seribu. This research is a descriptive study with a sample of 6 people conducted by \\
observation and data analysis in the form of tabulations and narratives. The results of the study \\
about the uses of masks and gloves before taking action is to use an appropriate mask by $100 \%$ \\
while the appropriate gloves by 56\% -89\%. The appropriate uses of masks and gloves after \\
taking action are 33\% -67\% of masks while gloves by 83\% - 100\%. The conclusion of this study \\
is the management of PPE prior to and after taking action on dental health workers in the Public \\
Health Center of North Kepuluan Seribu consisting of Public Health Centers in Pulau Harapan \\
and Public Health Centers in Pulau Pangang have been well implemented.
\end{tabular}

Korespondensi Penulis:

Virginia Rizkaevita

Jl. Abdul Rahman Saleh No. 18 Jakarta Pusat, Indonesia

Email: virginiarizka99@gmail.com

(C) Jurusan Keperawatan Gigi Poltekkes Kemenkes Jakarta I

Jl. Wijaya Kusuma No. 47-48 Cilandak Jakarta Selatan, Indonesia

email: jdht@poltekkesjakarta1.ac.id 


\section{Pendahuluan}

Puskesmas adalah fasilitas pelayanan kesehatan yang menyelenggarakan upaya kesehatan masyarakat dan perorangan tingkat pertama mengutamakan upaya promotif dan preventif (Sutarjo, 2018). Puskesmas memiliki beberapa tenaga kesehatan yang mengabdikan diri dalam bidang kesehatan serta memiliki pengetahuan dan keterampilan melalui pendidikan di bidang kesehatan (Kemenkes, 2014).

Tenaga kesehatan memiliki risiko terpapar infeksi silang dan penyakit menular. Jenis penyakit menular diantaranya TB Paru, Hepatitis, HIV, ISPA dan lainlain. Infeksi silang adalah perpindahan penyakit antara pasien dan petugas kesehatan dalam lingkungan kesehatan. Perpindahan infeksi memerlukan beberapa persyaratan yaitu adanya sumber infeksi, perantara dan cara perpindahannya. Upaya mencegah terjadinya infeksi silang pada petugas kesehatan maka perlu menggunakan Alat Pelindung Diri (APD). APD adalah alat yang digunakan untuk melindungi petugas dari risiko paparan darah, semua jenis cairan tubuh, dan selaput lendir pasien. APD terdiri dari sarung tangan, masker, kacamata pelindung, pakaian pelindung, dan penutup kepala (Mulyanti, 2019).

Hasil penelitian Nurmalia, dkk (2019), menunjukkan bahwa $54,39 \%$ penggunaan sarung tangan yang dilakukan oleh perawat tidak sesuai, sedangkan penggunaan masker dan apron hampir seluruhnya benar. Menurut Kemenkes (2016), pelayanan kesehatan gigi dan mulut menurut jenis kelamin menunjukkan bahwa angka rasio tumpatan/pencabutan di Kepulauan Seribu adalah 0,3 dari 6 puskesmas. Kepulauan Seribu memiliki rasio terendah dibandingkan kabupaten/kota lain di provinsi DKI Jakarta.

\section{Metode}

Jenis penelitian ini adalah deskriptif dengan cross sectional. Penelitian ini menggunakan teknik quota sampling. Penelitian dilakukan di Puskesmas Kecamatan Kepulauan Seribu Utara. Subyek penelitian adalah petugas kesehatan gigi. Penelitian dilakukan pada bulan Januari 2020. Penelitian ini dilakukan untuk mengetahui tatalaksana penggunaan APD sebelum melakukan tindakan pada petugas kesehatan gigi.

Jenis data yang dikumpulkan adalah jenis data sekunder yang diperoleh secara tidak langsung dari pihak puskesmas berupa data tenaga kesehatan dan data primer yang diperoleh langsung dari responden melalui lembar observasi. Data yang telah terkumpul kemudian diolah secara manual kemudian dilakukan

(C) Jurusan Keperawatan Gigi Poltekkes Kemenkes Jakarta I

Jl. Wijaya Kusuma No. 47-48 Cilandak Jakarta Selatan, Indonesia email: jdht@poltekkesjakarta1.ac.id analisa data. Analisa data disajikan dalam bentuk tabulasi dan narasi, dihubungkan dengan kepustakaan yang berkaitan dengan penggunaan APD.

\section{Hasil}

Hasil penelitian yang dilakukan tentang adalah sebagai berikut :

Tabel 1 penggunaan APD sebelum tindakan

\begin{tabular}{ccccc}
\hline & \multicolumn{4}{c}{ Masker } \\
\cline { 2 - 5 } Nama & Sesuai & Persentase & $\begin{array}{c}\text { Tidak } \\
\text { Sesuai }\end{array}$ & Persentase \\
\hline A & 3 & $100 \%$ & - & - \\
B & 3 & $100 \%$ & - & - \\
C & 3 & $100 \%$ & - & - \\
D & 3 & $100 \%$ & - & - \\
E & 3 & $100 \%$ & - & - \\
F & 3 & $100 \%$ & - & - \\
\hline & \multicolumn{5}{c}{ Sarung Tangan } \\
Nama & Sesuai & Persentase & Tidak & Pesuai \\
& 6 & $67 \%$ & 3 & $33 \%$ \\
A & 6 & $67 \%$ & 3 & $33 \%$ \\
B & 6 & $56 \%$ & 4 & $44 \%$ \\
C & 5 & $67 \%$ & 3 & $33 \%$ \\
D & 6 & $89 \%$ & 1 & $11 \%$ \\
E & 8 & $89 \%$ & 1 & $11 \%$ \\
F & 8 & &
\end{tabular}

Tabel 1 diatas menunjukkan bahwa persentase paling tinggi dari penggunaan masker sebelum melakukan tindakan yang sesuai sebesar $100 \%$, sedangkan yang tidak sesuai sebesar $0 \%$. Persentase paling tinggi dari penggunaan sarung tangan sebelum melakukan tindakan yang sesuai sebesar $89 \%$, sedangkan yang tidak sesuai sebesar $44 \%$. Persentase paling rendah dari penggunaan sarung tangan sebelum melakukan tindakan yang sesuai sebesar 56\%, sedangkan yang tidak sesuai sebesar $11 \%$.

Tabel 2 penggunaan APD sesudah tindakan

\begin{tabular}{ccccc}
\hline & \multicolumn{4}{c}{ Masker } \\
\cline { 2 - 5 } Nama & Sesuai & Persentase & $\begin{array}{c}\text { Tidak } \\
\text { Sesuai }\end{array}$ & Persentase \\
\hline A & 2 & $67 \%$ & 1 & $33 \%$ \\
B & 2 & $67 \%$ & 1 & $33 \%$ \\
C & 1 & $33 \%$ & 2 & $67 \%$ \\
D & - & - & 3 & $100 \%$ \\
E & 1 & $33 \%$ & 2 & $67 \%$ \\
F & 2 & $67 \%$ & 1 & $33 \%$ \\
\hline & \multicolumn{5}{c}{ Sarung Tangan } \\
Nama & Sesuai & Persentase & Tidak & Persentase \\
\cline { 2 - 5 } & 5 & $83 \%$ & 1 & $17 \%$ \\
A & 6 & $100 \%$ & - & - \\
B & 5 & $83 \%$ & 1 & $17 \%$ \\
C & 5 & $83 \%$ & 1 & $17 \%$ \\
E & 6 & $100 \%$ & - & - \\
F & 6 & $100 \%$ & - & - \\
\hline
\end{tabular}


Tabel 2 diatas menunjukkan bahwa persentase paling tinggi dari penggunaan masker sesudah melakukan tindakan yang sesuai sebesar 67\%, sedangkan yang tidak sesuai sebesar $100 \%$. Persentase paling tinggi dari penggunaan sarung tangan sesudah melakukan tindakan yang sesuai sebesar $100 \%$, sedangkan yang tidak sesuai sebesar $17 \%$. Persentase paling rendah dari penggunaan masker sesudah melakukan tindakan yang sesuai sebesar 0\%, sedangkan yang tidak sesuai sebesar $33 \%$. Persentase paling rendah dari penggunaan sarung tangan sesudah melakukan tindakan yang sesuai sebesar $83 \%$, sedangkan yang tidak sesuai sebesar $0 \%$.

\section{Pembahasan}

Pembahasan diatas didukung penelitian sebelumnya yang menunjukkan bahwa prosedur penggunaan APD yang sesuai memiliki presentase tinggi artinya hampir seluruh responden pada penelitian ini melakukan prosedur yang sudah ditetapkan (Sukaldo, 2017). Menurut Nurmalia, dkk (2019), motivasi tenaga kesehatan berkaitan dengan kepatuhan penggunaan APD dan prosedur penggunaan APD. Hal yang mempengaruhi penggunaan APD pada tenaga kesehatan adalah rasa takut dan tidak nyaman, seperti tenaga kesehatan takut akan tertular penyakit pasien, terkena cairan mulut pasien, dan rasa tidak nyaman untuk bersentuhan langsung dengan darah, cairan mulut pasien, luka pasien dan mencium aroma yang kurang sedap dari pasien tersebut.

Ketersediaan dan pengawasan mengenai APD juga menjadi berpengaruh. Kurangnya ketersediaan APD juga bisa mempengaruhi emosi tenaga kesehatan sehingga tenaga kesehatan menjadi takut, tidak aman dan tidak nyaman. Pengawasan yang kurang juga merupakan hal yang mempengaruhi prosedur penggunaan APD dan kondisi juga menjadi tidak aman, hal tersebut bisa menyebabkan kecelakaan kerja (Zaki, 2018).

Penelitian yang dilakukan oleh Zubaidah, dkk (2015), menunjukkan bahwa hampir seluruh tenaga kesehatan menggunakan APD yang sesuai dengan faktor risiko fisik yaitu masker dan sarung tangan. Hasil observasi yang dilakukan masih terdapat tenaga kesehatan yang tidak menggunakan APD selama bekerja, hal tersebut menyebabkan tenaga kesehatan berpotensi tertular penyakit. Meningkatkan kesadaran dan pengetahuan, mengubah sikap dan perilaku tentang APD merupakan tujuan penting untuk menurunkan risiko tertular penyakit.
Hasil penelitian yang dilakukan oleh Laranova, dkk (2018), menyatakan bahwa kepatuhan tenaga kesehatan terhadap penggunaan APD harus lebih diperhatikan, prosedur penggunaan APD juga harus di pertegas oleh institusi kesehatan.

\section{Kesimpulan dan Saran}

Penatalaksanaan APD sebelum dan sesudah melakukan tindakan pada petugas kesehatan gigi di Puskesmas Kecamatan Kepulauan Seribu Utara telah dilaksanakan dengan baik.

Saran yang dapat diberikan adalah hasil penelitian ini dapat digunakan sebagai acuan puskesmas untuk melengkapi alat pelindung diri dan melakukan pengawasan terhadap tenaga kesehatan khususnya tenaga kesehatan gigi tentang prosedur penggunaan alat pelindung diri. Hasil penelitian ini dapat digunakan sebagai acuan tenaga kesehatan untuk meningkatkan kepatuhan tenaga kesehatan dalam penggunaan masker dan sarung tangan sesuai prosedur.

\section{Daftar Pustaka}

Kemenkes RI. (2014). Peraturan Menteri Kesehatan Republik Indonesia No 75 tentang Pusat Kesehatan Masyarakat.

Kemenkes RI. (2016). Profil kesehatan DKI Jakarta tahun 2012. Jakarta: Pusdatin.

Laranova, A., Afriandi, I., dan Pratiwi, Y. S. (2018). Persepsi tenaga kesehatan terhadap penggunaan alat pelindung diri dan kejadian kecelakaan akibat kerja di salah satu rumah sakit di kota Bandung. JSK, Vol 3 (4), 189-197.

Mulyanti, S., dan Putri, M. H. (2019). Pengendalian infeksi silang di klinik gigi. Jakarta: EGC.

Nurmalia, D., Ulliya, S., Neny, L., Hartanty, A. A. (2019). Gambaran penggunaan alat pelindung diri oleh perawat di ruang perawatan rumah sakit. Journal of Holistic Nursing and Health Science, Vol 2 (1), 45-53.

Sukaldo, E., Komalasari, R., dan Hasibuan, S. Y. (2017). Gambaran penerapan alat pelindung diri di ruang peraawatan rumah sakit. Nursing Current, Vol 5 (2), 1-7.

Sutarjo, U. S. (2018). Profil kesehatan indonesia tahun 2017. Jakarta: Kementrian Kesehatan Republik Indonesia. 
Zaki, M., Ferusgel, A., dan Siregar, D. M. S. (2018). Faktor-faktor yang memengaruhi penggunaan alat pelindung diri (APD) tenaga kesehatan perawat di RSUD DR. RM. Pratomo Bagansiapiapi kabupaten Rokan Hilir. Excellent Midwifery Journal, Vol 1 (2), 85-92.

Zubaidah, T., Arifin, dan Jaya, Y. A. (2015). Pemakaian alat pelindung diri pada tenaga perawat dan bidan di Rumah Sakit Pelita Insani. Jurnal Kesehatan Lingkungan, Vol 12 (2), 291-298.

(C) Jurusan Keperawatan Gigi Poltekkes Kemenkes Jakarta I Jl. Wijaya Kusuma No. 47-48 Cilandak Jakarta Selatan, Indonesia email: jdht@poltekkesjakarta1.ac.id 